\title{
Healing and reconciliation as a pastoral ministry in post-conflict South African Christian communities
}

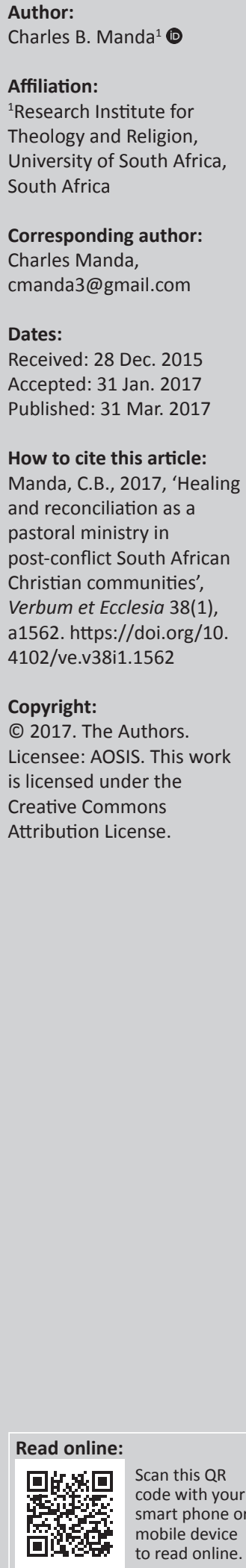

\begin{abstract}
Although Jeremiah's lamentation is directed towards the wound of God's people in Zion, Africa remains the site of struggle for political, socio-economic and religious freedoms. Is there no balm in Africa to heal the wound of God's people? This article examined the principles of healing and reconciliation as understood in the South African cosmology and how or whether they could be applied by the pastoral ministry to enhance the recovery and restoration of African Christian communities in post-conflict situations. To get the relevant data, the authors engaged literature written on these concepts of healing and reconciliation and how they are applied in a broader context. The authors also used their experiences in the field of healing to illustrate some points.

Intradisciplinary and/or interdisciplinary implications: Although the article is focussed on the role of the pastoral ministry within the South African cosmology, this study has interdisciplinary implications in the disciplines of peacebuilding, mental health and psychosocial support. The author argues that when these social and cultural aspects of healing and reconciliation are taken into consideration, they could enhance post-conflict reconstruction and social transformation of post-conflict African communities.
\end{abstract}

Listen to the cry of my people, from a land far away: ... 'The harvest is past, the summer has ended, and we are not saved'. Since my people are crushed, I am crushed; I mourn, and horror grips me. Is there no balm in Gilead? Is there no physician there? Why then is there no healing for the wound of my people? (Jr 8:21-23 New International Version [NIV])

\section{Introduction}

The purpose of the article is to explore the meaning of healing and reconciliation in African cosmology and how these social concepts could be applied in post-conflict Christian communities. By the term Christian communities, the author refers to churches, Christian faith-based organisations and any community that claims to live by Christian principles and values. Healing and reconciliation play a major role in African cosmology, and the question is whether these principles are enough to address the needs of African Christian post-conflict communities. Postconflict communities are those communities where there is:

fragile democracy and violent transition where many people lack meaningful access to forums of political power, the question of how to achieve redress, reconciliation, justice and ultimately healing or recovery is often an elusive one, and studies show that people tend to turn to the spiritual realm for answers and deeper social redress. (University of Pretoria 2013:5)

The first section of the article discusses a broader understanding of healing and reconciliation, and how these concepts are understood in a wide variety of African communities. The second section explores some healing and reconciliation rituals, both within and outside of the Christian context, which the pastoral ministry could apply to heal and reconcile post-conflict Christian communities. In other words, what contribution could these rituals, and approaches to healing and reconciliation make as applied to post-conflict African communities?

South African democratic society emerges from a past which is littered with interpersonal and interracial conflicts. Manda (2015:1) argues that despite the change from Apartheid to a democratic government, South Africa continues to experience multiple-woundedness through trauma and the burden of disease. The effects of this:

multiple-woundedness can be seen everywhere in South Africa, and it is hampering the true political and economic development as so many people have to live with pain. This pain prevents them from making a significant contribution to their communities. (Denis, Houser \& Ntsimane 2011:2)

Therefore, there is a need to find ways of healing South African communities so that people can participate in their own healing and transformational development. 
There is a growing literature on healing and reconciliation rituals, both within and outside of the Christian context, that are being practised in South Africa.

Although reconciliation is understood as the healing of broken interpersonal relationships, and that this is not a unique understanding of reconciliation within the framework of a South African cosmology, the findings suggest that within an African cosmology healing involves God, the spirits, other people and the whole of creation. In other words, healing and reconciliation are not only focussed on interpersonal relationships but rather the inclusion of the whole of creation and the spirit world. The inclusion of the spiritual, creation and ancestors may not be as present in other African and non-African cosmologies on healing and reconciliation. Therefore, the article brings an interesting starting point for understanding the unique perspective that African cosmology on healing and reconciliation brings to other African and non-African contexts, which have been, as Mbiti (2010) puts it, '... severely wounded by the roughness of ugly struggles in political, social, economic, and religious spheres'.

Akoto and Akoto (2005:35-36) define the term cosmology as a body or system of thought arising out of a people's history and culture that addresses issues of reality and creation, truth and value, meaning, process and people's place within creation. Mugambi (2002) calls this a worldview. According to Mugambi:

The epistemological foundation of every culture is its basic world-view. All other layers of a culture may be seriously damaged through conquest or internal disruption, but the foundation is likely to remain intact. (p. 116)

In this article, the authors examine the fundamental principles of healing and reconciliation as understood and applied to a South African worldview.

The term 'healing' has diverse meanings depending on which context or field of study it is used. For example, in the medical field, Lartey (2007:62) argues that healing presupposes that we have lost something we once enjoyed and that there is a possibility to regain what we have lost. This hope to regain what we have lost is seen in the endless search in the medical professionals worldwide for drugs that can confront incurable diseases (Ndung'u 2009:87). On the other hand, Louw (2013:1-13) asserts, 'healing in Christian spirituality is not merely the healing of a private human soul detached from the body, the existential realities and the ecological environment'. Instead, Christian spirituality deals with the cosmic implications of the work and death of Christ as well. It strives for the whole human being to become 'whole'. The term 'Whole' here is used in the context of Apostle Paul's prayer for the Church in Thessalonica:

May God himself, the God of peace, sanctify you through and through. May your whole spirit, soul and body be kept blameless at the coming of our Lord Jesus Christ. (1 Th 5:23)
Magezi (2006:505-521) takes this further. He says, theologically, healing refers to the event of being transformed from a condition of death into a condition of life. This new condition is an indication of a new state of being: being accepted unconditionally by grace and being restored into a new relationship with God, a relationship of peace, reconciliation and forgiveness. Therefore, healing call for a holistic understanding of the concept and this article explores healing in the African context. The following sections attempt to define the concept of healing as understood in African cosmology.

\section{Healing in African cosmology}

The first social concept discussed in this article is healing. Lugira (2004:13) maintains that the traditional African worldview is that suffering is caused by sins and misdeeds that offend the gods and ancestors, or by being out of harmony with society. Even Mbiti (1969:2) in his book, African religions and philosophy, is of the view that: 'to be human is to belong to the whole community, and to do so involves participating in the beliefs, ceremonies, rituals and festivals of that community'. For this reason, argues Magezi (2006:506), 'healing must be facilitated by the community'.

Mbiti (1969:108-109) supports Magezi's assertion because whatever happens to the individual happens to the whole group, and whatever happens to the group happens to the individual. Hence the Ubuntu saying, 'I am, because we are, and since we are, therefore I am'. Therefore, for Ndung'u (2009:87-104), the term 'healing' implies the putting in order of those systems, structures and feelings which have been disrupted causing imbalances and suffering in the life of individuals and society at large. Thus healing in the African context involves the restoration of broken relationships, between the individual with God, ancestors, community or others.

\section{Reconciliation in African cosmology}

The second social concept is reconciliation. Lartey (2007:65) is adamant that reconciliation involves bringing together again parties that have become estranged or alienated from each other. The word reconciliation in Greek is katallage referring to the restoration of the sinner to fellowship with God clearly showing that reconciliation is one aspect of Christ's ministry (Stamps 1992:1418). In his epistle to the Church of Corinth, Apostle Paul writes:

All this is from God, who reconciled us to himself [sic] through Christ and gave us the ministry of reconciliation: that God was reconciling the world to himself in Christ, not counting men's sins against them. And he [sic] has committed to us the message of reconciliation. (2 Cor 5:18-19 NIV)

The biblical understanding of reconciliation is not very far from the African understanding in that in both cosmologies the word 'restoration of relationship' is key. As a broken relationship spells disaster for the individual and, by extension, for the rest of the family and society at large in 
African cosmology (Ndung'u 2009:87), it is necessary that a remedy is sought to bring back the wholeness of life to the people.

Jesus places more weight on the reconciliation or repairing broken relationships than rushing for prayer. In order for reconciliation between God and the individual to take place, he or she must be at peace with other people. In African cosmology, reconciliation goes beyond God and fellow neighbour. Ndung'u (2009:87) asserts that 'people are at peace when their relationship with God, the spirits, other people and the rest of creation is good'. Lugira (2004:13) alleges that human society in African cosmology is communal. This means ancestors, the living, the living-dead and those yet to be born are all an important part of the community. The relationships between the worldly and the other-worldly help to guide and balance the lives of the community (2004:13). However, these relationships can be broken between a person and his or her support systems. When this happens, ritual actions may relieve the problems and sufferings of human life. This relief may come either by satisfying the offended gods or by resolving social conflicts. Thus rituals are vehicles that help facilitate the restoration of people to the traditional values and renew their commitment to a spiritual life (2004:13). So whether people break up because of harsh conditions or something wrong has happened, Thorpe (1991:24-25) maintains, 'a remedy has to be sought to bring back the wholeness of life to the people'.

Therefore, healing and reconciliation must be seen as going hand-in-hand in African cosmology.

\section{Healing and reconciliation in South African Christian communities}

While the first section of this article explored the meaning of social concepts such as healing and reconciliation, the second section focusses on how these social concepts could be applied in post-conflict Christian communities. In other words, it discusses what contribution these rituals, and approaches to healing and reconciliation can make as applied to post-conflict African communities.

Louw (2013:9) suggests that in order for healing and reconciliation to happen in post-conflict African Christian communities, the pastoral ministry should focus on liberation. Gutierrez (n.d.) argues that the word Liberation carries three levels of meaning:

the political liberation of oppressed peoples and social classes; man's liberation in the course of history; and liberation from sin as condition of a life of communion of all men with the Lord. (p. 248)

Gutierrez (n.d.:248) argues that if you speak of liberation, you hint at the biblical sources that illuminate man's or woman's presence and actions in history such as the liberation from sin by Christ our Redeemer and the bringing of new life. One such biblical source is Paul's second epistle to the Church in Corinth (2 Cor 5:18-19) where he articulates:
All this is from God, who has reconciled us to himself [sic] through Christ and gave us the ministry of reconciliation: that God was reconciling the world to himself [sic] in Christ, not counting men's [sic] sins against them. And he [sic] has committed to us the ministry of reconciliation.

Through Christ's death, God has removed the barrier of sin and opened a way for the sinner to return to God (Stamps 1992:1812). Thus, in order for us to deal with the past in a constructive way or what Gutierrez (n.d.:248) calls 'man's [sic] liberation in the course of history', Louw (2013:9) argues that it is paramount that we disclose and face the truth of our existence. He further contends that we need pastoral ministry to focus on spiritual healing which entails forgiveness and reconciliation (Louw 2013:9). However, although Louw focusses on spiritual healing which entails forgiveness and reconciliation, Mbiti argues that Africa has sustained multiple- wounds and as such these wounds may need multi-dimensional approach to heal the body, the mind, the soul, and the whole society (Mbiti 2010). A focus that takes into account, spiritual healing only does not meet the three dimensions of liberation that Gutierrez (n.d.:248) articulates. I agree with Volf (2006) who criticises the role that churches as presumed instruments of peace, in the face of violent conflict have so often played, making them often impotent, at best, or perpetrators of violence, at worst. Volf (2006) and Wielenga (2013) argue further that talking about reconciliation from the pulpit is not enough but that the social meaning of reconciliation needs to become a reality in church practice.

One may ask: How does healing and reconciliation become a reality in South African Christian communities? It is difficult to prescribe one-size-fits all 'to-do-list' for pastoral ministry to heal the South African Christian communities in postconflict situations. Nevertheless, the following sections reflect on some rituals, both within and outside of the Christian context, that the pastoral ministry could apply to heal and reconcile post-conflict South African Christian communities.

\section{Koinonia encounters}

The second ritual is Koinonia encounters. Wielenga (2013:7) defines Koinonia encounters as creating safe spaces for people to share their stories. Wielenga (2013:7) urges churches 'to plan to have story-sharing encounters around a meal or a braai fire at the church on a regular basis'. She challenges congregations that have outreaches to impoverished communities to take the time to hear stories from the community and share their own stories which have the potential of transforming the encounter from the problematic one of the 'rich' congregation patronising the poorer one to a mutual sharing and learning experience. For Wielenga, this is the way forward to minister healing and reconciliation in and across divided congregations and communities.

Pastoral ministry can take advantage of the fact that a majority of African Christians live in rural communities of Africa where reading and writing may be problematic. Nevertheless, storytelling or African oral tradition continues 
to flourish as a medium of transmitting intergenerational knowledge, intergenerational trauma, hatred, bitterness from one generation to another. Thus, Wielenga challenges the churches to learn from organisations that are involved in 'making public spaces intimate' for people to share their stories. In particular, Wielenga (2013:7-8) draws our attention to the work of the Institute for Healing of Memories (IHOM) and African Enterprise, two South Africa-based organisations. Both organisations have experience in facilitating healing in multiracial congregations and also across the globe. IHOM (n.d.:5) contends that for healing to happen, people need to remember their hurts, tell their stories and be accepted/ respected/listened to. For healing to happen, we need to learn to listen to each other. Listening is a gift we can give to people. Listening is also hospitality. IHOM argues further that when you listen to someone you are offering them space in which to feel welcome, to meet, to be listened to, to be heard, to feel safe and to be free to be himself or herself (n.d.:5). In almost all Healing of Memories workshops, I have been part of across the globe, I have observed the tension between silence and disclosure that was palpable amongst participants at the beginning of the workshop. However, the creation of safe spaces gave participants permission to share their life stories.

Therefore, it is the role of pastoral ministry to facilitate this healing process so that people can further their journeys towards healing, peace and reconciliation.

\section{Why storytelling?}

One may ask why storytelling is so important in the healing and reconciliation of Christian communities in South Africa and elsewhere on the continent. Storytelling is a powerful tool to bring healing to individuals and communities that are 'broken and bruised in so many ways' (Lartey 2007:62). Whether the story is told around the fire, in a dance, or through drama, it is important that survivors in post-conflict situations tell their story. The importance of storytelling is coined by several scholars.

Firstly, Herman (1992:1) argues that 'remembering and telling the truth about terrible events are prerequisites both for the restoration of the social order and for the healing of individual victims'. She adds: 'when the truth is finally recognised, survivors can begin their recovery'. Phiri, Govinden and Nadar (2002:10) cite Mercy Oduyoye who argues that 'Africans need to tell stories as the art of storytelling is an integral part of who we are as Africans'. Phiri et al. (2002:10) add, 'The art of storytelling goes back centuries, and the important function that stories serve in African communities cannot be under-estimated'. For example, storytelling serves the function of remembrance, warning, teaching and lending meaning. We must be clear from the beginning that storytelling is not limited to Africans only; it is a gift for all humanity to utilise and find the healing they need.

Secondly, Phiri et al. (2002:10) argue that storytelling creates space for theologians to find their voice. Wielenga concurs with Phiri and adds that telling the story enables people 'to give voice to their suffering, ritualise it, objectify it, reopen the wound to better let it out, let it heal, let it scar over'. Similarly, Rigby (2001:129) gives another imagery of what happens when we tell our stories. 'By confessing our pain we uncover the pain of the past which is portrayed as a poisonous wound that needs to be lanced and exposed to the fresh air', if true healing is to take place. For example, part of the process of lancing and exposing the wounds of post-conflict South Africa, was the process of Truth and Reconciliation Commission (TRC) public hearings in the late 1990s. Thus, perpetrators and victims of gross human rights violations alike flocked to the designated centres, church and community halls all over South Africa to tell their side of the story and be listened to. Because TRC made 'public spaces intimate' for both perpetrators and victims, they were able to confront and confess their pain, with the hope to recover faith, hope and meaning in life.

Thirdly, Denis et al. (2011) concur with Betancourt:

the telling of one's story of woundedness to a person in a safe environment who cares may open the door to a journey of healing which leads to a better life. (p. 5)

They argue that although the telling itself does not annihilate the painful experiences wounded people have gone through, however, telling of a story does enable people to domesticate their bad memories so that the past remains, but it ceases to haunt them. Betancourt (2010:13) takes this further and describes how sharing stories can heal. She says, 'remembering is painful and telling your story involves submerging yourself deeply and intensely in your own past, bringing forth a flood of uncontrolled emotion':

But sharing is also your way out because every time you tell your story, you can distance yourself from it, take a step back and you learn to remember without reliving, and begin to recover. (Betancourt 2010:13)

\section{A drama of forgiveness}

The third ritual is a drama of forgiveness. In his book No future without forgiveness, Tutu (1999) argues that it is in all our interests to try to restore social harmony once it has been fractured. He contends that:

to forgive others and welcome them back into our common human household is not altruistic, it is the highest form of enlightened self-interest, insofar as it affirms the humanity of the other, and hence of ourselves, and thereby helps restore community. (pp. 34-36)

Rigby (2001:129) agrees with Tutu and adds, 'Forgiveness helps us to let go of the pain of the past in order that we do not remain trapped in the confines of the past injuries and injustices'. In this section, we discuss a drama of forgiveness which Daye (2004:7) presents in his book, Political Forgiveness: Lessons from South Africa. In his model of a drama of forgiveness, Daye presents five acts. It is like a drama group is performing on stage showing one act after another. In illustrating different acts, we use a moving example of 
the story of forgiveness that surfaced during the TRC in South Africa.

Act One in a drama of forgiveness is truth-telling, that is, the naming and articulation of the harm done. Daye (2004:7-8) asserts that somebody must point out that one party's unjust action (or inaction) has damaged another party or caused that second party to suffer. He adds that usually, it will be the victimised party that makes this statement and begins the narrative of wrong done. However, Daye also acknowledges that on rare occasions the guilty party first names the offense, but its narrative usually begins in step two, that is, apology and the claiming of responsibility. This is true with the South African TRC where either the victims or perpetrators applied to testify at the TRC public hearings.

Act Two in a drama of forgiveness is apology and the claiming of responsibility or confession (Daye 2004:7). Here the guilty party does not only tell the truth about the harm that was done, they admit to the wrong done and acknowledge its moral indebtedness to the party they have harmed. For example, in her book Truth and Reconciliation in South Africa: Miracle Or Model, Graybill (2002:47) tells a story of Corrie Pyper who asked for amnesty during the TRC in South Africa for the killing of Vuyani Papuyana, a student and taxi driver. According to the report by SAPA (25 March 1998), on the evening of 27 April 1994, Pyper and Wheeler 'attacked a minibus loaded with black passengers on the road between Westonaria and Randfontein. The driver, Vuyani Papuyana, was shot dead and his brother Godfrey was wounded'. Wheeler and Pyper, both in an intoxicated state on Election Day in 1994, decided to kill blacks in an effort to disrupt the elections. During the TRC process, Wheeler turned to late Vuyani's family, asking, 'Can you forgive me? I cannot believe I was so short-sighted! I have decided never again to resort to violence to achieve a political objective' (SAPA 1998). This brings us to Daye's third act in a drama of forgiveness.

Act Three is building a transitional-justice framework (Daye 2004:9). It is in this act that forgiveness is offered by the victimised party. According to Daye, just as many offenders refuse to apologise, many victims refuse to forgive. However, Daye admits that it is surprising how often people are willing to forgive even before apologies are offered. Graybill (2002:47) adds that many victims forgive not because their tormentors deserve it, but because they need to do it for the sake of their own inner freedom. Nelson Papuyana, the father of late Vuyani, is a case in point. He says that to face the man ( $\mathrm{Mr}$ Pyper) who murdered his son was the best thing he had ever done. He says, 'The meeting helped me to overcome my emotional problems' (Graybill 2002:47). Daye cautions that sometimes victims may offer a pardon that is qualified by calls for further repentance or some kind of restitution, but, in its ideal form, forgiveness is offered fully with no strings attached. In the case of Papuyana, his family never demanded anything as a condition of forgiveness, neither did it ask for restitution. But it was Mr Pyper who offered restitution. In an act of contrition, Pyper had offered to pay for the funeral costs and offered R5200 to the Papuyana family. Mr Papuyana says, 'I at first refused to accept it, but when he insisted I could see that it would relieve his pain if I accepted it. He felt better afterwards' (Graybill 2002:47). In this case, restitution serves both parties with relief.

Act Four in a drama of forgiveness seeks to find ways to heal. Daye (2004) asserts that when a nation has been rent by prolonged violence or tyranny, a number of kinds of healing are needed. In a case where there have been gross human rights violations like in South Africa or other communities emerging from conflict, individuals will suffer from traumatic stress disorders and will have particular therapeutic needs that centre on issues of empowerment and security. Although we are not told whether Mr Papuyana sought psychiatric treatment or not, his listening to the murderers of his son, in a way got him started on a healing journey. Papuyana says, 'The meeting helped me to overcome my emotional problems' (Graybill 2002:47).

Act Five of Daye's drama of political forgiveness is the embracing of forgiveness. The embracing of forgiveness involves the reformation of whole communities at a level so deep that collective identities are transformed. This kind of communal 'soul work', as Daye (2004:62) puts it, requires revision of the very myths and narratives that tell a person who they are and their friends and enemies are. In the case of Pyper, he noted, 'I was wrong to believe that we were not members of the same (moral) community', or to put it in other words, 'I was wrong to believe that my humanity and your humanity were not of the same order' (Daye 2004:62). This was the beginning of the transformation of collective identity in South Africa. Graybill (2002:48) gives another example of embracing forgiveness. Another TRC applicant was Eric Taylor, who faced the families of his victims, four activists from the Eastern Cape referred to as the Cradock Four, whom he had killed. Taylor said:

I am here in response to God's prompting and I fully believe that He [God] has forgiven me. I also applied for amnesty and although it is not a certainty, amnesty may be granted. But amnesty is a technical matter and will do nothing towards reconciliation. I have realised that the only way to find peace is to tell the families, wives, children, brothers and sisters that I am sorry for a lot that happened and to ask them if they can find strength through God to forgive me. (p. 48)

In response to Taylor's plea for forgiveness, the son of Matthew Goniwe, one of the Cradock Four, embraced the White police man and said: 'You murdered our father. But we forgive you!' (Graybill 2002:48). However, it is not granted that families of the victims will forgive the perpetrator; as Daye (2004:8) has mentioned it in Act Three, 'just as many offenders refuse to apologise, many victims refuse to forgive'.

Therefore, it is the duty of the pastoral ministry who are facilitating or mediating the drama of forgiveness to support the families as they struggle to forgive the perpetrators. But it is important that victims find forgiveness for their own personal freedom. 


\section{A 'dance' of reconciliation}

The fourth step on our to-do list for pastoral ministry in this article is 'a dance of reconciliation'. In African cosmology, reconciliation is a long process as one has to make peace with all parties involved, which include God, spirits, the living, and the living-dead and other people. Both Ndung'u (2009:87) and Thorpe (1991:24-25) do agree that because a broken relationship spells disaster for the individual, and, by extension, for the rest of the family and society at large in African cosmology, it is necessary that a remedy is sought to bring back the wholeness of life to the people. The remedy mentioned in African cosmology is what Daye calls restitution. For example, in Act Three of forgiveness, we looked at the example of Pyper who offered to pay for the funeral costs and R5200 to the Papuyana family in restitution or as a remedy. Although no amount of restitution can replace the lost life, it is a token that releases the grace for the victims to heal and reconcile with their enemies.

In order to understand the process of reconciliation, in this section, we discuss how the pastoral ministry can apply the dance of reconciliation as a tool to heal and reconcile Christian communities in post-conflict situations. Nussey (2014:7) in her article: The dance of reconciliation..., expresses how complex a journey of reconciliation is especially in postconflict societies. Using the example of South Africa, Nussey argues that one difficulty is to negotiate a space and place where victims, perpetrators, beneficiaries and bystanders can live together in relative harmony after a successful transition in the political sphere. In her study, Nussey reveals that efforts to promote reconciliation in South Africa, as in many post-conflict countries, show that structural changes in the political sphere do not necessarily lead to individual and social attitudes changing in the short term (Nussey 2014:2). Therefore, Nussey suggests the use of John Lederach's imagery of the dance of reconciliation as a way to bring healing and reconciliation to post-conflict communities like South Africa. Both Nussey (2014) and Wielenga (2013) agree on Lederach's model of the dance of reconciliation as the way forward to heal, not only South Africa or African communities, but also any community that is in need of healing and reconciliation. Wielenga argues that Lederach's four-part model is drawn from Psalm 85:10. 'Mercy and truth are met together; righteousness and peace have kissed each other' (KJV).

Thus, Lederach's model encompasses mercy, truth, justice and peace. In this model, Lederach argues that all four elements of this model need to be in balance in order for reconciliation to become a reality. Nussey takes Lederach's model further and adds one more dancer on the stage Hope. According to Nussey different dancers simultaneously have activities taking place on the stage related to the past (Truth), the present (Justice and Mercy), and the future (Hope and Peace). Therefore, in order for societies, emerging from wars and human rights violations, to heal and reconcile, it is the pastoral mandate to facilitate the dance of reconciliation by engaging the five dancers: Truth, Justice and Mercy, and Hope and Peace. For this to happen, the pastoral ministry ought to create safe spaces where individuals, groups and communities can publicly confess and share their wrongs and human rights violations. There is no better example for the church to engage in a dance of reconciliation than that which is embodied in the person of Archbishop Tutu during the TRC hearings in South Africa. Rigby (2001) asserts:

it was Tutu, sitting at hearings with his cassock and his crucifix, under the banner 'Truth- The Road to Reconciliation', who came to symbolise the South African truth and reconciliation process. (p. 136)

As an African theologian, deeply embedded in the African values of Ubuntu, pairing amnesty (Mercy) with Justice in the dance of reconciliation articulated alternative conception of justice-restorative justice embodied in the concept of Ubuntu as opposed to retributive justice. Tutu (1999:34-36) argued that it is in all our interests to try to restore social harmony once it has been fractured. Thus he focussed more on restoring the moral and social order rather than insisting on 'an eye for an eye' as many South Africans would have lost their eyes. As such TRC was the result of a political compromise deeply embedded in the African philosophy of life, which aimed at restoring social harmony and community.

In this article we argue that African Christianity needs to take into consideration 'the dance of reconciliation' because it is God's requirement that people heal and reconcile. Micah asks:

... And what does the Lord require of you? To act justly and to love mercy and to walk humbly with your God. (Mi 6:8 NIV)

\section{Conclusion}

This article began by exploring the meaning of healing and reconciliation in African cosmology, and how these social concepts could be applied in post-conflict African Christian communities. Several rituals, and approaches to, healing and reconciliation were explored to see how they could be applied to post-conflict African communities. The findings show that in the African cosmology, healing comes as a result of restoration or reconciliation of broken relationships between the individual and community. The community includes God, the spirits, other people and the rest of creation. Therefore, the concepts of healing and reconciliation work hand-in-hand in African cosmology. The study also established that healing of the community is more significant in African cosmology than the healing of individual persons. However, whether it is the individual or community that is broken and bruised, rituals play significant role to restore the communal moral and social order. As African oral tradition continues to flourish as a medium of transmitting intergenerational knowledge, and at times even intergenerational trauma, hatred and bitterness from one generation to another, the study has recommended the adoption of storytelling as one of the tools that the pastoral ministry could use to facilitate healing and reconciliation 
of post-conflict African Christian communities. Whether the story is told around the fire, in a dance or through drama, regardless the method, it is important for pastoral ministry to open safe spaces for people in post-conflict Christian communities to, in the words of Rigby, lance and expose their wounds to the air through storytelling so that they begin to heal.

While we engage in storytelling, we should incorporate a drama of forgiveness and a dance of reconciliation to instil the values and importance of forgiveness, truth, justice, mercy, hope and peace. As African Christian communities understand the African worldview of offering remedy, the pastoral ministry should encourage the offering of restitution as a process of healing and reconciliation in post-conflict communities.

The implications will be a restoration of the communal moral and social order in post-conflict African Christian communities which will result in the surviving individuals and communities restoring faith, hope and meaning in life.

\section{Acknowledgements \\ Competing interests}

The author declare that he has no financial or personal relationships that may have inappropriately influenced him in writing this article.

\section{References}

Akoto, K.A. \& Akoto, A.N., 2005, 'African cosmology', in M.K. Asante \& A. Mazama (eds.), Encyclopedia of black studies, Sage, Thousand Oaks, CA. viewed 23 December 2015, from https://doi.org/10.4135/9781412952538.n13

Betancourt, I., 2010, Even silence has an end: My six years of captivity in the Colombian Jungle, Penguin Press HC, New York.

Daye, R., 2004, Political forgiveness: Lessons from South Africa, Orbis Books, New York.

Denis, P., Houser, S. \& Ntsimane, R., 2011, A journey towards healing: Stories of people with multiple woundedness in KwaZulu-Natal, Cluster Publications, Pietermaritzburg.
Graybill, L.S., 2002, Truth and reconciliation in South Africa: Miracle or model?, Lynne Rienner Publishers, London.

Guiterrez, G., n.d., Notes for a theology of liberation, Peru, cdn.theologicalstudies.net

Herman, J.L., 1992, Trauma and recovery: The aftermath of violence from domestic abuse to political terror, Basic Books, New York.

Institute for Healing of Memories, n.d., Facilitators' guidelines: Healing of memories workshops, Institute for Healing of Memories, Cape Town.

Lartey, E.Y., 2007, In living color: An intercultural approach to pastoral care and counselling, 2nd edn., Jessica Kingsley Publishers, London.

Louw, D.J., 2007, Cura vitae. Illness and the healing of life. A guide for caregivers, Lux Verbi, Wellington.

Louw, D.J., 2013, 'Cura vitae: The hermeneutics of spiritual healing and the beautification of life', Scriptura 112(1), 1-16, viewed 15 December 2015, from http://scriptura.journals.ac.za

Lugira, A., 2004, African religion: World religions, rev. edn., Facts On File, Inc., New York.

Magezi, V., 2006, 'Community healing and the role of pastoral care of the ill and suffering in Africa', In die Skriflig 40(3), 505-521. https://doi.org/10.4102/ids. v40i3.356

Mbiti, J.S., 1969, African religions and philosophy, Heinemann Educational Books Ltd, Nairobi.

Mbiti, J.S., 2010, 'Peace and reconciliation in African Religion', Dialogue \& Alliance 24(1) (Spring/Summer), viewed 26 November 2015, from http://www.upf.org/ resources/speeches-and-articles/3226-js-mbiti-peace-and-reconciliation-inafrican-religion

Mugambi, J.N.K., 2002, Christianity and African Culture, Action Publishers, Nairobi.

Ndung'u, N.W., 2009, 'Persistence of Features of Traditional Healing in the Churches in Africa: The Case of the Akurinu Churches in Kenya', Thought and Practice: A Journal of the Philosophical Association of Kenya (PAK) New Series 1(2), 87-104.

Nussey, R., 2014, 'The "dance" of reconciliation: Understanding the complex steps in a reconciliatory pedagogy using an oral history assignment', Yesterday \& Today, No. 12, December 2014, pp. 1-28.

Phiri, I.A., Govinden, D.B. \& Nadar, S., 2002, Her-stories: Hidden histories of women of faith in Africa, Cluster Publications, Pietermaritzburg.

Rigby, A., 2001, Justice and reconciliation: After the violence, Lynne Rienner Publishers, London.

South African Press Agency, 1998, Rightwinger admits to being drunk in 1994 attack on blacks, South African Press Agency, Pretoria.

Stamps, D.C., 1992, The full life study bible: For Charismatic Christians, Zondervan Publishing House, Grand Rapids, MI.

Thorpe, S.A., 1991, African traditional religions: An introduction, University of South Africa, Pretoria.

Tutu, D., 1999, No future without forgiveness, Rider, London.

University of Pretoria, 2013, Templeton proposal: The meaning of Ubuntu in human and social development in Africa, University of Pretoria, Pretoria.

Volf, M., 2006, The end of memory: Remembering rightly in a violent world, Eerdmans, Grand Rapids, MI.

Wielenga, C., 2013, 'Shattered stories: Healing and reconciliation in the South African context', Verbum et Ecclesia 34(1), Art. \#747, 1-8. https://doi.org/10.4102/ve. v34i1.747 